\title{
Testing Weak Form of Stock Market Efficiency at The Indonesia Sharia Stock Index
}

\author{
Isnaini Nuzula Agustin ${ }^{1 *}$ \\ ${ }^{1}$ Fakultas Ekonomi Universitas Internasional Batam, Indonesia
}

Submitted: April 23, 2019, Accepted: June 24, 2019, Published: June 27, 2019

\begin{abstract}
Efficient Market is the market where all traded securities prices reflects all available information. Market Efficient Hypotesis in the Weak Form stated that past stock price movement incorporated with current securities's prices, thus it can be used to predicting the current price or return. The objective of this research is to examine the weak form of Efficient Market Hypothesis (EMH) in Indonesia Sharia Stock Index (ISSI) over the period of January 3rd2017 -February 8th 2019. To Examine the EMH, some appropriate tests are developed, these are: Run Test, Autocorrelation Test, Autoregressive Integrated Moving Average (ARIMA), and Paired Sample t-test. The result findings showing that ISSI is not efficient in the weak form during the period of the study. Moreover, in accordance with time series modelling result, the fitted model is ARIMA $(1,1,1)$ with accuracy level of 78\%. This result proved that ARIMA model successfully and accurately in forecasting ISSI indices. It can be implied that the historical stock index data in the past still described the stock index information in the future. Thus, technical analysis is still feasible to do as the guide for investors in conducting transactions in the capital market.
\end{abstract}

Keywords: efficient market hypothesis; Indonesia sharia stock index; run test; autocorrelation test; technical analysis

\begin{abstract}
Abstrak
Pasar yang efisien adalah pasar dimana semua harga sekuritas yang diperdagangkan telah mencerminkan semua informasi yang tersedia. Teori pasar efisien bentuk lemah menyatakan bahwa perubahan harga masa lalu tidak berhubungan dengan harga sekuritas sekarang, sehingga tidak dapat digunakan untuk memprediksi harga atau return dari sekuritas. Penelitian ini bertujuan untuk melakukan pengujian hipotesis pasar efisien bentuk lemah pada Indeks Saham Syariah Indonesia (ISSI). Data diambil pada periode 3 Januari 2017 - 8 Februari 2019. Pada tahap awal penelitian, Run test dan Autocorrelation test dilakukan untuk melihat apakah pasar efisien bentuk lemah berlaku pada ISSI. Selanjutnya dilakukan pembentukan pemodelan time series ARIMA untuk melihat teknik prediksi yang sesuai untuk memprediksi Indeks Saham ISSI. Hasil Run test dan Autocorrelation test menunjukkan bahwa hipotesis pasar efisien bentuk lemah tidak terbukti. Pada pembentukan model ARIMA, terlihat bahwa model yang sesuai adalah ARIMA $(1,1,1)$ menghasilkan tingkat akurasi sebesar $78 \%$. Hal ini membuktikan bahwa model ARIMA berhasil dan akurat digunakan untuk memprediksi Indeks Harga Saham ISSI. Oleh karena itu, analisis teknikal masih dapat digunakan oleh investor untuk menjadi pedoman dalam melakukan transaksi perdagangan di pasar modal.
\end{abstract}

Kata Kunci: hipotesis pasar efisien; indeks saham syariah Indonesia; uji run; uji autokorelasi; analisis teknikal 


\section{INTRODUCTION}

Capital market is one part of financial market that carries out both financial and economic functions. In terms of the economy, the capital market is a place to allocate funds efficiently from parties who have funds to those who need funds. Meanwhile from its financial function, activities in the capital market aim to obtain returns for those who allocate funds according to the type of investments that have been chosen. In this case, the capital market is a meeting place among parties who need funds (the demand side) and those who provide funds (the supply side), with the certain risk and return. For companies, the capital market is a means to increase long-term needs by distributing stocks or bonds. Companies will issue securities, either shares or bonds, and then offer them to parties that provide funds (investors).

In trading activities in the capital market, one of the prominent focuses for investors is the market efficiency. An efficient market is a market where all prices of traded securities reflect all available information. Such information can be in the form of corporate earning reports, dividend distribution, stock splits, and reports from capital market analysts. The Efficient Market Hypothesis introduced by Fama in 1970 embodies a prominent role in the development of financial theory (Andrianto \& Mirza, 2016). This Information divides into three groups, namely the past stock price information, the public information and, all existing information including the private information. Each information group shows the level of market efficiency, namely the weak form efficient, the half-strong form efficient, and the strong form efficient.

The testing of weak form market efficiency is aimed to investigate how strong the past information can predict future returns, thus the weak form of market efficiency involves the question of whether the information contained in successive past securities prices has fully reflected current prices. If this hypothesis is proven, then it means that changes in past prices are uncorrelated to current securities prices so it cannot be used to predict prices or returns from securities. As a result, technical analysis instruments used to predict stock prices, as well as providing signals to buy, hold, or sell, become meaningless. Conversely if it is not proven, it means that investors can make predictions with techniques or tools that use the time series analysis technique.

Several researches concerning the Efficient Market Hypothesis on the Indonesia Stock Exchange have been conducted using different objects, periods, research methods, and statistical tests. Those researches also give different results even in the same objects can give different conclusions if done in different periods or time frames.

Andrianto and Mirza (2016) conducted a research to test the efficient market hypothesis in the weak form in Indonesia. The stock index data taken is the LQ45 Index, Jakarta Islamic Index, and Kompas 100, in the period of 2013 - 2014. By using conventional statistical analysis run test and serial correlation, this research produces two conclusions, namely that the movement of stock prices in Indonesia follows the principle of random walks, and there is no correlation or no relationship between today's stock price and stock prices in previous periods. This shows that this research has proven that the stock market in Indonesia is efficient in the weak form. The results of this research are in line with the researches conducted by Cahyadin and Milandari (2009), Nikita and Soekarno (2012), and Hase and Haryono (2018). 
Shaik (2017) conducted the weak form efficient market hypothesis test on countries registered as ASEAN members, using the variance ratio test and exponential ratio test method. The test results show that the weak form efficient market does not exists in Indonesia, Malaysia, Philippines, Thailand, and Vietnam; while in Cambodia, Laos, and Singapore, have an efficient market in the weak form. The results of this research are in accordance with the researches conducted by Guidi and Gupta (2011) and Gunarso, Siregar and Irawan, (2017). Although using different stock indices objects, these researches conclude that capital markets in Indonesia tend to be inefficient. The movement of daily historical stock prices does not show the random walk, indicates the existence of serial correlations in the time series data.

Utami (2018) conducted the weak form efficient market hypothesis test in three different countries, namely Indonesia, Malaysia, and Korea. This research observed changes in the level of efficiency in three different periods, namely the period before, during, and after the global crisis. By taking the Indonesian Stock Indices (IHSG) as the historical stock data in Indonesia, this research concluded that there was different efficiency in the market over these periods. Before the global crisis, IHSG showed efficient market in a weak form; during the global crisis, the IHSG was inefficient; and after the global crisis, the IHSG market conditions were even unstable, between efficient and inefficient.

Meanwhile, many researches aimed to test Efficient Market Hypothesis have also been carried out in other countries, both developed and developing countries. One of them is the research conducted by Ang and Weber (2018), which took the population of Dow Jones Sustainability Index Korea in the period of January 2006 to December 2015. To analyze the rate of efficiency, researchers used several statistical tests, namely run test, Dickey Fuller Test, Philip Perron Test, Variance Ratio Test. The results of the research stated that the weak form efficient market hypothesis is not proven in this stock index. Therefore, stock price movements in Korea can be predicted based on the available historical data. Ren and Ren (2017) using Mean Absolute Deviation in order to investigate the rate of market efficiency in United Stated Stock Indices. They used simulated data which appropriate to the characteristics of US Stock Indices. This research shows similar result stated that the Efficient Market Hypothesis in US market is not proven.

Considering the changes in stock market movements in developed countries during the global crisis, Sabbaghi and Sabbaghi (2018) studied the level of efficiency of the stock market by taking data in the period of January 2008 - November 2011. During this period, it was proven that most developed countries followed the market pattern of the efficient weak form. This is because investors tend to be more emotional and actively seek information during the crisis period.

One of time series prediction techniques that have been widely used is Box Jenkins Analysis or technically defined as Autoregressive Integrated Moving Average (ARIMA). In Various researches, ARIMA proved to produce high accuracy for short term prediction. In Addition, ARIMA method also more applicable because it accommodates unstationaired data at level, but stationair at differencing level.

Shaik (2017) conducted technical analysis study on National Stock Exchange (India), using sample size of 50 companies which registered in Nifty Index during the 
Isnaini Nuzula Agustin, Testing Weak Form of Stock Market Efficiency at The Indonesia...

period of January to December 2015. The result shows that by using ARIMA, stock prices can be predicted with the goodness of fit given 94\%. It also produces low Mean Absolute Precentage Error, and the appropriate ARIMA model is ARIMA $(0,1,1)$ with the lowest BIC value. Meanwhile, Lusikooy, Nainggolan, and Titaley (2017) conducted research which aimed to applying ARIMA model in order to predict daily closing stock price of PT Garuda Indonesia Tbk, during the period of October $25^{\text {th }}$ to November $7^{\text {th }}$ 2016. Based on this research, the best model is ARIMA $(3,1,3)$ with the smallest Mean Squared Error namely 63.7\%.

Lilipaly, Hatidja, and Kekenusa (2014) conducted research aimed to predict stock prices of Bank Rakyat Indonesia Tbk using daily stock closing prices during the period of January 2011 to October 2014. This research produces results showing that ARIMA model is appropriately predicting stock prices for the period of November 2014. ARIMA model for both maximum and minimum stock price is ARIMA $(2,1,3)$. Those several researches is in accordance with researches has been done by Ayo (2014), Mondal, Shit, and Goswami (2014), Devi, Sundar and Alli (2013), which stated that ARIMA produces high accuracy, relatively low MSE, and appropriately used to predict short term future prices.

The Indonesia Stock Exchange (IDX) noted that the number of sharia model market investors until the end of 2018 had reached 44,000 or $5.2 \%$ of the total number of capital market investors in Indonesia. This number jumped $92 \%$ compared to 2017 , i.e., the growth of sharia capital market investors was very high in 2018 . Thus the potential of Islamic stocks is very high, as many as $80 \%$ of the shares on the IDX, include sharia shares or around almost 400 issuers, and liquidity in sharia shares contributes $80 \%$ (cnbcindonesia.com, 2019).

This research uses the Indonesian Islamic Stock Index as the object of research. The Indonesian Sharia Stock Index (ISSI) is a composite of shares containing all shares listed on the Exchange and fulfilling sharia criteria, in contrast to Jakarta Stock Index (JII) which is limited to 30 sharia companies. The sharia indices opens opportunities for investors who want to invest in the stock market without contradicting Islamic sharia, although often debate arises among scholars, but it cannot be denied that Islamic stock market capitalization is increasing from year to year. When first opened in 2011, ISSI's market capitalization stood at IDR 1,968 trillion, and in August 2018 the market capitalization at ISSI, which contained 381 shares, had reached IDR 3,586.0 trillion or $52.4 \%$ of the total capitalization of listed shares on the Indonesia Stock Exchange (www. syariahsaham.com, 2019). This shows very large investors interested in this stock index. Indonesia, with a majority of the Muslim population, certainly wants an Islamic shariabased investment instrument.

Based on those explanations, it is obviously shows that the researches aimed at testing the weak market efficient form hypothesis in Indonesia, provide inconsistent results. These inconsistencies are partly due to differences in research objects, data analysis methods, and research periods. Most of those researches have stalled on the analysis of whether the weak form efficient market is proven or not; even though the part that has to be observed is, if the efficient market hypothesis is not proven, what prediction techniques are suitable for forecasting stock prices in the future. Therefore 
this research will complement previous studies by conducting appropriate time series prediction techniques. Furthermore, the size of the ISSI market capitalization makes the prediction of return movements and stock prices on this index interesting to study. In addition, the weak form efficient market hypothesis test performed on the sharia index is still not found in Indonesia. On this basis, researcher wants to conduct research to test the weak form of efficient market hypothesis in the ISSI stock index.

The problem statements for this study are to find the existence of efficient market in the weak form in ISSI stock index, and to find the appropriate prediction techniques to be used to predict the ISSI stock index.

\section{RESEARCH METHODOLOGY}

This research is categorized as quantitative research because it uses numerical data in decision making techniques. In terms of the relationship between variables, this research is classified as the comparative causal research because it looks at the relationship or influence between the past and the future data. This research is using the secondary data, namely the ISSI closing price index data, taken from the yahoo finance website in the period of January 3, 2017, to February 8, 2019. The data were analyzed by using SPSS (Statistical Package for Social Sciences) version 22.0.

Several stages of the analytical method that will be used in this research are respectively as follows: Run Test, Autocorrelation test, ARIMA modelling and paired sample t-test. Run Test was performed in order to see the movement pattern of the ISSI stock price index. Random patterns indicate that stock price index data is difficult to predict and tends to contain all information available in the capital market. Conversely, non-random patterns indicate that ISSI stock price index data can be predicted based on patterns formed in previous periods. Runs Test uses $\mathrm{Z}$ statistics, where the $\mathrm{p}$ value is $>0.05$ indicates that ISSI's daily stock price index data is random or difficult to predict. Autocorrelation with the L-Jung Box statistical method aims to detect the serial autocorrelation in the time serial data. If the test results show that there are at least two significant lags ( $\mathrm{p}$ value is $<0.05$ ), then there is a serial autocorrelation in the time serial data, and vice versa. While ARIMA modelling is one of the prediction techniques which widely used. The ARIMA modeling requires the data to be stationary to get good predictive results. Therefore, the formation of the ARIMA model begins with the stationarity test on the data. If the data is not stationary, then the differencing process is carried out where the level of differentiation will be the $d$ order in the ARIMA model. The $p$ and $q$ orders can be determined directly through a significant number of lags on the autocorrelation and partial autocorrelation corelograms. In Addition, the paired t-test was performed to see the predictive power of the produced ARIMA model. Significant differences between the actual data and the predicted data indicate that the ARIMA model is less accurate, and vice versa. 


\section{RESULT AND DISCUSSION}

The first stage in this research is performing Run Rests, which aimed to see the randomness of data. Based on daily closing price ISSI indices, table 1 which is the result, it has been showed the significance value of 0.000 , or less than error level 0.05 . It means that daily closing prices on ISSI is not walk randomly. Therefore, Random Walk Hypothesis theory is not exists on ISSI during the periode of January $3^{\text {rd }} 2017$ to February $8^{\text {th }} 2019$.

Table 1. Result of Runs Test

\begin{tabular}{lr}
\hline & \multicolumn{1}{c}{ Closing Price } \\
\hline$Z$ & -19.454 \\
Asymp. Sig. (2-tailed) & $.000^{*}$ \\
\hline *significant at $\alpha=0.05$ &
\end{tabular}

The next step is Autocorrelation test specifically using L Jung Box Statistics, which aimes to investigate the correlation among time series data (current price and its lagged price). This following table 2 is the result of Autocorrelation Test.

Table 2. Result of L-Jung Box Statistic Test

\begin{tabular}{cccl}
\hline Lag & Autocorrelation & Box-Ljung Statistic & Sig. \\
\hline 1 & .968 & 471.906 & $.000^{*}$ \\
2 & .940 & 918.591 & $.000^{*}$ \\
3 & .916 & 1343.186 & $.000^{*}$ \\
4 & .895 & 1749.258 & $.000^{*}$ \\
5 & .874 & 2137.176 & $.000^{*}$ \\
6 & .857 & 2510.947 & $.000^{*}$ \\
7 & .840 & 2870.542 & $.000^{*}$ \\
8 & .817 & 3211.852 & $.000^{*}$ \\
9 & .795 & 3535.310 & $.000^{*}$ \\
10 & .772 & 3840.868 & $.000^{*}$ \\
11 & .751 & 4131.126 & $.000^{*}$ \\
12 & .736 & 4410.506 & $.000^{*}$ \\
13 & .721 & 4678.751 & $.000^{*}$ \\
14 & .703 & 4934.823 & $.000^{*}$ \\
15 & .686 & 5178.648 & $.000^{*}$ \\
16 & .666 & 5408.782 & $.000^{*}$ \\
\hline
\end{tabular}

*significant at $\alpha=0.05$ 
The Result of Run test supported by result of autocorrelation test using L-Jung Box Statistic, which shows that among 16 lagged has been developed, all lags having the significance value of 0.000 , or less than error level 0.05 . It is implies that there is significant correlation between time series data.

In accordance with the result of Run Test and Autocorrelation Test, it has been proven that daily closing price Index on ISSI is not randomly distributed. There was correlation constituent among each time series data. Thus, it can be concluded that this market is inneficient, i.e. the previous price still being important keys in predicting future prices. This finding is consistent with previous researchs conducted by Shaik (2017), Gunarso et al (2017), and Guidi and Gupta (2011), but seems contradict with most others researches conducted by Andrianto and Mirza (2016), Cahyadin and Milandari (2009), Nikita and Soekarno (2012), and Hase and Haryono (2018). Similar research conducted by Andrianto and Mirza (2016) which using Jakarta Islamic Index as the research's object shows that Indonesia stock market has decreased efficiency. Some conditions that make the market inefficient and likely to happen to the company over the study period was due to some investors may affect the price of securities of the company. In this case, some companies alleged to have access to information that can only be reached by some investors only, and the rapid development of technology supports speeds decision making. In order to achieve better development of sustainable capital markets, it is necessary to have efficiency in this stock markets. It is known that if markets are inefficient, it becomes difficult to raise the capital through the markets which will hinder the viable investment projects. With the continuous increase of number of investors in ISSI, it becomes essential to safeguard the wealth of the investors. The policy maker should introduce legal and regulatory frameworks which can bring positive sentiment for potential investors. This could be assisted by introducing further reforms for improving legal and regulatory framework as well as increasing standards of transparency and internal controls.

Furthermore, ARIMA analysis has been developed to see prediction accuracy of previous data toward future data. The assumption underlying ARIMA technique is that data must be stationary. Figure 1 shows the result of stationary test before differencing process.

Based on Figure 1, it is indicates that data instationary at level. Thus, it needs to be stationarized by differencing process. Figure 2 as the result of differencing process, shows that data stationary after first differencing. It means that $\mathrm{d}=1$ will be orde 1 in ARIMA that will be used. By using orde $\mathrm{d}=1$, tests for some combination of tentative models has been performed in order to find best ARIMA models.

Based on table 3, it has been shown that among twelve models that has been performed, ARIMA $(1,1,1)$ were chosen as the best model due to smallest Root Mean Square Error. Thus, this model will be used to predict daily closing stock price indices of ISSI.

Table 4 shows model coefficients for each predictor variables, including its significance values. Based on table, it is proved that lagged 1 data significantly influence toward its future data, shown by significance value which is less than 0.05 . It means that Stock Price Index for ISSI influenced by its previous data, and its previous residuals. All of coefficients will be substituted into ARIMA model as follows. 


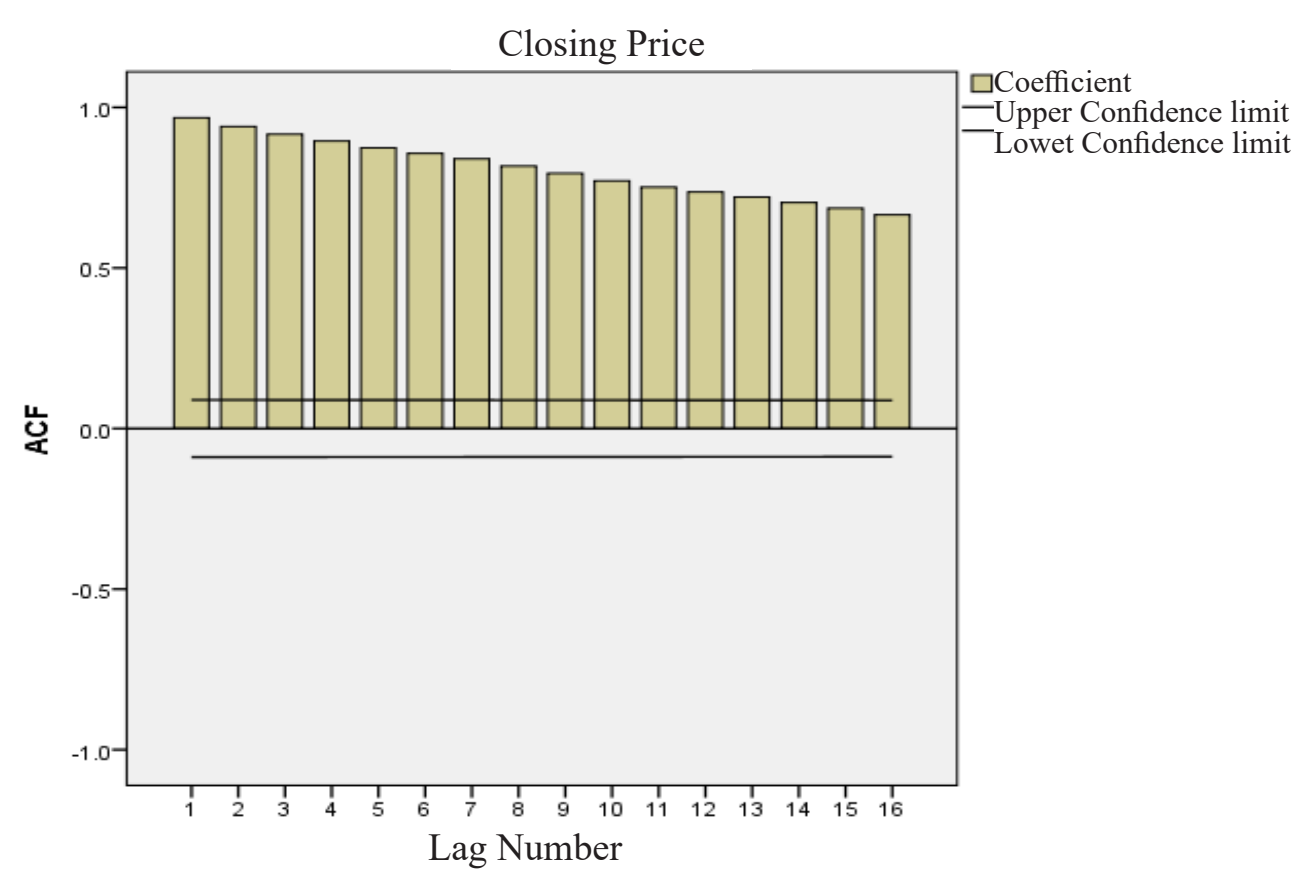

Figure 1. Correlogram of Autocorrelation Function before Differencing Process

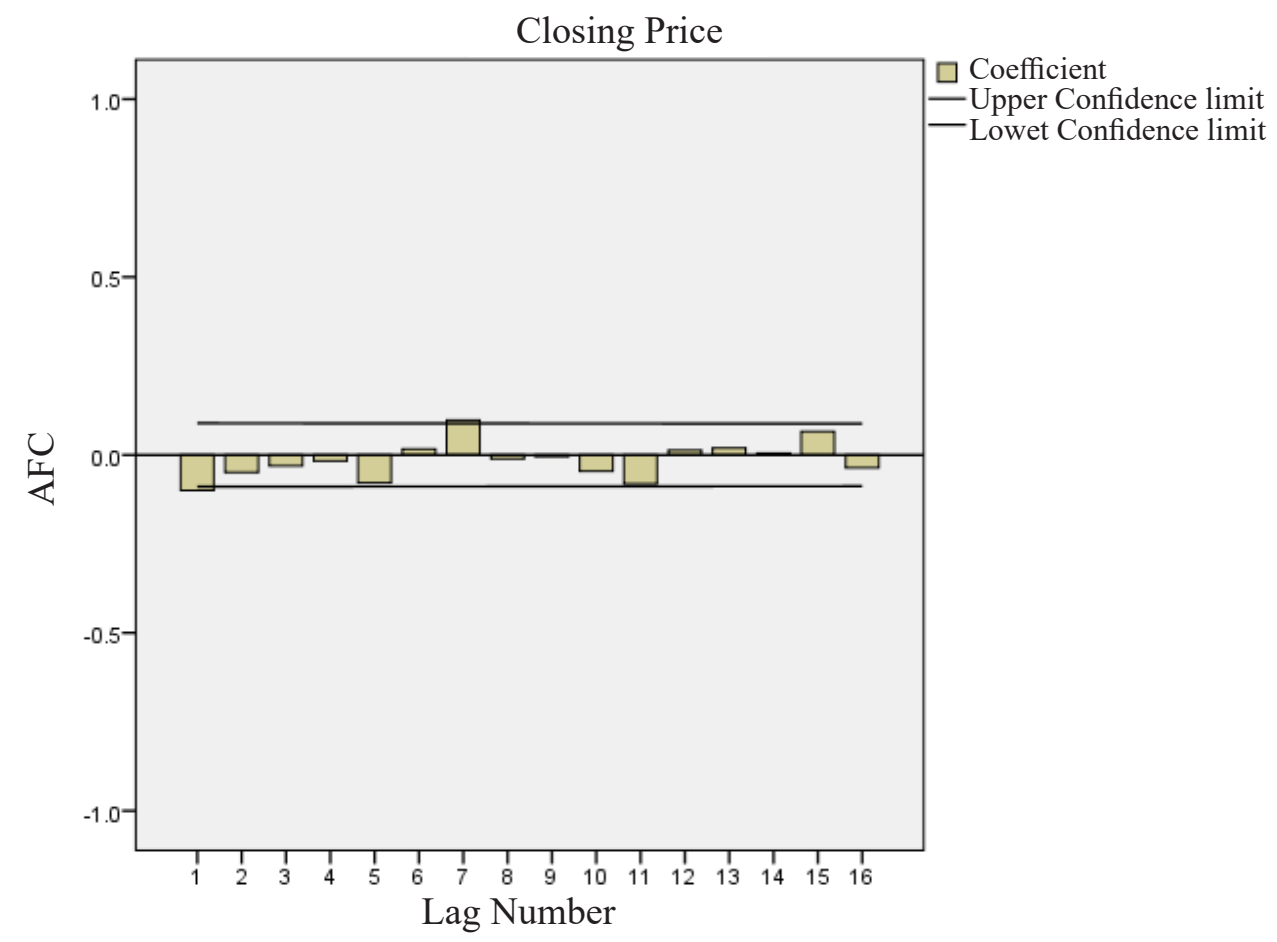

Figure 2. Correlogram of Autocorrelation Function after Differencing Process 
Table 3. Goodness of Fit Tentative Models

\begin{tabular}{cc}
\hline Tentative Model & RMSE \\
\hline$(1,1,0)$ & 1.538 \\
$(1,1,1)$ & 1.533 \\
$(2,1,1)$ & 1.535 \\
$(3,1,1)$ & 1.537 \\
$(1,1,2)$ & 1.535 \\
$(1,1,3)$ & 1.537 \\
$(2,1,0)$ & 1.537 \\
$(2,1,2)$ & 1.536 \\
$(2,1,3)$ & 1.537 \\
$(3,1,0)$ & 1.537 \\
$(3,1,2)$ & 1.537 \\
$(3,1,3)$ & 1.538 \\
\hline
\end{tabular}

Therefore, equation model of ARIMA $(1,1,1)$ for predicting future daily closing stock price indices of ISSI is as follows:

Table 4. Coefficients of ARIMA $(1,1,1)$ models

\begin{tabular}{ccc}
\hline Variable & Coefficients & Significance \\
\hline Constant & 0.045 & 0.380 \\
AR (1) & 0.579 & $0.004^{*}$ \\
MA(1) & 0.688 & $0.000^{*}$ \\
\hline
\end{tabular}

\section{*significant at $\alpha=0.05$}

ARIMA $(1,1,1)$ equation model produces R Square value of $78 \%$, which is fairly high, means that this model gives high accuracy prediction, i.e the predictors able to explain its response variables by value of $78 \%$. In term of time series, it means that previous daily closing price able to predict future daily closing price at value of $78 \%$.

The main requirement for time series to be approved as best model is that model has to be white noise residuals. In order to examine the fulfillment of this requirement, it needs to develop correlogram of the residuals that has been produced.

Figure 3 shows that error or residuals is insignificant, which means that residuals tend to be white noise, i.e ARIMA $(1,1,1)$ model can be used for prediction.

As the final stage of data analysis, Paired sampe t-test has been performed to see if there are significant differences between actual and prediction data. If there are no significant differences, it means that ARIMA $(1,1,1)$ model successfully forecast future daily closing price indices for ISSI. Otherwise, if actual and predicted data significantly different, then ARIMA $(1,1,1)$ failed to forecast this time series data. 


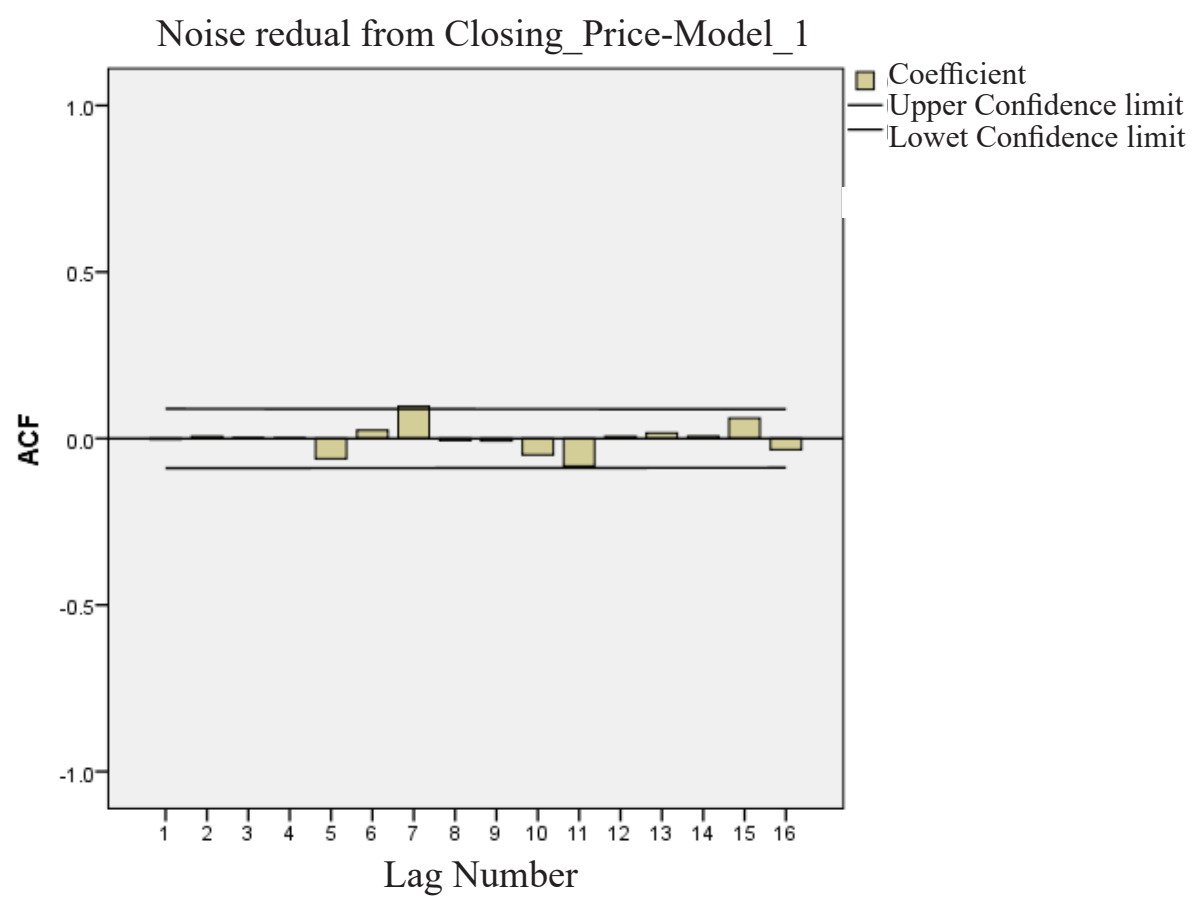

Figure 3. Noise Residual from Closing Price ARIMA $(1,1,1)$ model

Table 5. Result of Paired t-Test

\begin{tabular}{lcc}
\hline Pair & $\mathrm{t}$ & Sig. (2-tailed) \\
\hline $\begin{array}{l}\text { Pair 1 : Closing Price - Predicted value from Closing_ } \\
\text { Price-Model_1 }\end{array}$ & 0.010 & 0.992 \\
\hline
\end{tabular}

Table 5 shows that paired t-test produces significance value of 0.992 or higher than significance level of 0.05 . It is indicates that there is no significant differences between actual and predicted data. It also can be concluded that ARIMA $(1,1,1)$ able to forecast the daily closing price indices for ISSI successfully and accurately. This result is consistent with previous research conducted by Ashik and Kannan (2017), Ayo (2014), Lilipaly et al., (2014), Mondal et al., (2014) and Devi, Sundar, and Alli (2013).

Considering the results of the Run Test, it is proven that in the period of January 2017 to February 2019, the Islamic capital market in Indonesia, especially those incorporated in the Indonesian Sharia Stock Index (ISSI), shows the inefficiency market. Inefficient market means that investors are unable to respond quickly and precisely to all available information. Conventional financial theory assumes that investors always behave rationally in the process of making investment decisions. Rational investors will try to analyze all information obtained in investment decision making with the aim of reducing uncertainty, thus the rational explanation can be obtained in the decision making (Ackert \& Deaves, 2010). However, in its development, investors often show irrational behavior which results inefficient market conditions. Decisions made by investors who interpret information correctly result in the movement of stock prices in the market 
model does not reflect all existing informations (Forbes, 2009).

The capital market inefficiency is partly due to the movement of stock prices which are only dominated by a small number of investors who actively trade. The data from the Kustodian Sentral Efek Indonesia (KSEI) shows that at the end of 2018, the capital market grew significantly with the number of Single Investor Identification (SID) reaching 1.61 million or an increase of $44.06 \%$ from the end of 2017 . On the other hand, the Indonesia Stock Exchange acknowledged if the composition of the current capital market in Indonesia is not ideal. The percentage of institutional investors' share ownership is still quite dominant at $73 \%$, so transaction activity of institutional investors has become one of the benchmarks for retail investors in making transactions. Until now it turns out the dominance of institutional investors is considered to make the trading less attractive. Institutional investors tend to pursue dividend long-term profits so they are less active in trading. Therefore, trading activities are only influenced by a small number of individual investors or retailers with a composition of share ownership that is much smaller than institutional investors, which results in inefficient markets (Kustodian Sentral Efek Indonesia, 2018).

The ARIMA model $(1,1,1)$ successfully predicts the ISSI Daily Stock Index with the accuracy rate of $78 \%$. This result is supported by the paired sample $t$-test which states that there is no significant difference between the actual data and the predicted data using the ARIMA $(1,1,1)$ model. This proves that the historical stock index data in the past still described the stock index information in the future. The technical analysis is still feasible to do as the guide for investors in conducting transactions in the capital market.

\section{CONCLUSION}

Based on the research's results, it is proves that efficient market hypothesis is not applicable for Indeks Saham Syariah Indonesia (ISSI). This result has been concluded after performing Run Tests and Autocorrelation Test by using daily closing stock price index during the period of Januari $3^{\text {rd }} 2017$ to February $8^{\text {th }} 2019$. The market inefficiency partly due to the existence of irrational investors. This condition makes the movement of stock prices only dominated by a small number of active investors. As the result of developing time series modelling using ARIMA, it has been obtained that the best model is ARIMA $(1,1,1)$, producing the R squared value of $78 \%$, and the smallest value of Root Mean Square Error (RMSE). This model supported by Paired T-Test Result, which stated that there is no significant differences between actual and predicted data. It is implies that historical stock price data still able to described its future prices. Thus, investors still able to use appropriate technical analysis in order to gain optimal return.

\section{REFERENCES}

Ackert, L. F., \& Deaves, R. (2010). Behavioral Finance: Psychology, Decision-Making and Markets. Mason: South-Western Cengage Learning.

Amsi, M. (2019, February 14). Ikhtisar Statistik Saham Syariah Indonesia. Retrieved from http:// www.syariahsaham.com/2019/02/ikhtisar-statistik-indeks-saham-syariah.html.

Andrianto, Y., \& Mirza, A. R. (2016). A Testing of Efficient Markets Hypothesis In Indonesia Stock Market. Procedia - Social and Behavioral Sciences, 219, 99-103. https://doi. 
org/10.1016/j.sbspro.2016.04.048.

Ashik, M., \& Kannan, S. (2017). Forecasting National Forecast Using ARIMA Model. Global and Stochastic Analysis, 4(1), 77-81.

Ang, W. R., \& Weber, O. (2018). The Market Efficiency of Socially Responsible Investment in Korea. Journal of Global Responsibility, 9(1), 96-110, https://doi.org/10.1108/JGR-112016-0030.

Ayo, C. K. (2014). Stock Price Prediction Using the ARIMA Model. UKSim-AMSS $16^{\text {th }}$ International Conference on Computer Modelling and Simulation. https://doi.org/10.1109/ UKSim.2014.67.

Cahyadin, M., \& Milandari, D. O. (2009). Analisis Efficient Market Hypothesis (EMH) di Bursa Saham Syariah, 2005:1-2008:11. La_Riba: Jurnal Ekonomi Islam, 3(2), 223-236. https:// doi.org/10.20885/lariba.vol3.iss2.art6.

Forbes, W. (2009). Behavioral Finance. New York: John Wiley \& Sons.

Guidi, F., \& Gupta, R. (2011). Are ASEAN Stock Market Efficient? Evidence From Univariate and Multivariate Variance Ratio Tests. Discussion Papers in Finance, 201113, 488-502. Griffith University, Department of Accounting, Finance and Economics.

Gunarso, A., Siregar, H., \& Irawan, T. (2017). The Stock Market of Infrastructure Sector: A Weak-Form EMH Test. International Journal of Science and Research, 6(2), 2015-2018. https://doi.org/10.21275/ART20171092.

Hase, G. J., \& Haryono, N. A. (2018). Pengujian Efisiensi Pasar Pada Pasar Modal Indonesia Periode Juni 2009 - Juni 2015 (Studi Pada Indeks Harga Saham Gabungan). Jurnal Ilmu Manajemen Jurusan Manajemen Fakultas Ekonomi Universitas Negeri Surabaya, 6(4), $550-558$.

Kustodian Sentral Efek Indonesia. (2018, Desember 27). Berita Pers: Inovasi untuk Kenyamanan Transaksi di Pasar Modal. Retrieved from KSEI: http://www.ksei.co.id/publication/pressreleases.

Lilipaly, G. S., Hatidja, D., \& Kekenusa, J. S. (2014). Prediksi Harga Saham PT BRI Tbk Menggunakan Metode ARIMA ( autoregressive integrated moving average ). Jurnal Ilmiah Sains, 14(2), 60-67.

Lusikooy, J., Nainggolan, N., \& Titaley, J. (2017). Prediksi Harga Tutup Saham PT. Garuda Indonesia, Tbk Menggunakan Metode ARIMA. Jurnal MIPA Unsrat Online, 6(1), 74-77.

Mondal, P., Shit, L., \& Goswami, S. (2014). Study of Effectiveness of Time Series Modelling (Arima) In Forecasting Stock. International Journal of Computer Science Engineering and Application (IJCSEA), 4(2), 13-29. DOI: 10.5121/ijcsea.2014.4202.

Nikita, M. P., \& Soekarno, S. (2012). Testing on Weak Form Market Efficiency: The Evidence From Indonesia Stock Market Year 2008-2011.2 $2^{\text {nd }}$ International Conference on Business, Economics, Management and Behavioural Finance (BEMBS), 56-60.

Ren, L., \& Ren, P. (2017). Testing The Market Efficiency By Mean Absolute Deviation. Benchmarking: An International Journal, 24(7), 2049-2062. https://doi.org/10.1108/BIJ06-2016-0096.

Sabbaghi, O., \& Sabbaghi N. (2018). Market Efficiency and The Global Financial Crisis: Evidence From Developed Market. Studies in Economics and Finance, 35(3), 362-385, https://doi. org/10.1108/SEF-01-2014-0022.

Saleh, T. (2019, January 21). Investor Saham Syariah Sudah Capai 44.000. Retrieved from https:// www.cnbcindonesia.com/market/20190121162205-17-51636/investor-saham-syariahsudah-capai-44000.

Shaik, M. (2017). Market Efficiency of Asean Stock Market. Asian Economics and Financial Review, 7(2), 109-122. https://doi.org/10.18488/journal.aefr/2017.7.2/102.2.109.122. 
Devi, B. U., Sundar, D., \& Alli, P. (2013). An Effective Time Series Analysis for Stock Trend Prediction Using ARIMA Model for Nifty Midcap-50. International Journal of Data Mining \& Knowledge Management Process (IJDKP), 3(1), 65-78, DOI : 10.5121/ ijdkp.2013.3106.

Utami, A. T. (2018). Efisiensi Pasar Bentuk Lemah Pada Pasar Modal Indonesia, Malaysia dan Korea Selatan Periode Krisis Ekonomi Global 2008. Jurnal Inspirasi Bisnis dan Manajemen, 2(2), 101-116. 